\title{
Nilai-Nilai Pembelajaran Adabul Majlis bagi Generasi Emas Prasekolah Islam
}

\section{Devi Vionitta Wibowo}

Universitas Islam Negeri Sunan Kalijaga Yogyakarta

Jln. Laksda Adisucipto, Depok Sleman, Yogyakarta

Email:vionittadevi@gmail.com

\section{Naskah diterima: 16 Juli 2020, direvisi: 04 September 2020, diterbitkan: 23 September 2020}

\begin{abstract}
Abstrak
Artikel ini berisikan mengenai kajian keislaman bagi generasi Prasekolah di bidang pengembangan agama dan moral anak yang bertemakan adabul majlis yang bersumber pada Qur'anul Karim serta keilmuan Islam lainnya. Tujuan kepenulisan ini agar orangtua dan pendidik memperoleh keilmuan Islam mengenai pembelajaran adabul majlis bagi generasi emas prsekolah Islam serta mampu mengaplikasikan keilmuan kedalam pribadi keseharian anak. Metode penelitian menggunakan library reseach berupa kepustaka an secara deskripif analitik dengan menggunakan beberapa referensi tafsir serta keilmuan Islam generasi emas Prasekolah. Hasil artikel mengungkapkan bahwa terdapat dua surah dalam Qur'anul Karim yang memuat keilmuan adabul majlis, yaitu surah Al-Mujadalah ayat 11 yang menerangkan tentang kewajiban ikhlas serta mentaati protokol bermajlis sesuai peraturan yang telah ditetapkan. Surah Al-Baqoroh ayat 189 sebagai contoh aplikasi adabul majlis dengan memasuki rumah melalui pintu yang telah disediakan. Metode yang dapat digunakan berupa pembiasaan dalam bersikap sopan, santun, salam saat brmajlis, metode keteladanan guru, orangtua dalam mncontohkan prilaku yang baik saat bermajlis, metode nasehat digunakan untuk mengajarkan anak akan perbuatan terpuji, serta metode pengawan dilakukan untuk memerhatikan sosialisasi anak ketika bermajlis.
\end{abstract}

Kata kunci: Pembelajaran adab, Adabul Majlis, Generasi Emas, Prasekolah

\begin{abstract}
This article contains Islamic studies for the Preschool generation in the field of children's religious and moral development with the theme of adabul majlis which is sourced from the Qur'an and other Islamic scholarship. The purpose of this authorship is for parents and educators to obtain Islamic scholarship regarding the learning of adabul majlis for the golden generation of Islamic preschools and to be able to
\end{abstract}


apply science into the child's personal daily life. The research method uses reseach library in the form of descriptive analytic by using several interpretations references and Islamic science of Preschool gold generation. The results of the article revealed that there are two surah in the Qur'an that contain the scientific adabul majlis, namely surah Al-Mujadalah verse 11 which explains the obligation of sincerity and obeys moral protocols in accordance with established regulations. Surah Al-Baqoroh verse 189 as an example of the application of adabul majlis by entering the house through the doorprovided. The method that can be used in the form of habituation in being polite, greeting, exemplary methods of teachers, parents in exemplifying good behavior, advice methods are used to teach children about commendable deeds, and supervision methods carried out to pay attention to the socialization of children

Keywords: Adab learning, Adabul Majlis, Gold Generation, Preschool

\section{Pendahuluan}

Zaman sekarang merupakan era modernisasi bagi kaum milenial. Banyak beberapa tempat favorit yang kerap sekali ramai dikunjungi oleh berbagai kalangan, mulai dari orangtua, anak muda, bahkan kanak-kanak geneasi emas. Perlu diketahui bersama bahwa kanak-kanak generasi emas merupakan golongan kanak-kanak usia belia, yaitu antara usia 06 tahun. Situs pendidikan menyebutnya dengan masa prasekolah, yaitu kanak-kanak yang duduk di bangku TK/RA/BA atau yang sederajat. Para generasi emas, ikut andil dalamsosialiasi di era modern ini. Sosialisasi bagi generasi emas betujuan untuk mengembangkan perkembangan sosial antarapribadi mereka dengan masyarakat sekitar. Namun, dengan hal itu, tentunya para orangtualah yang berperan aktif dalam memilih tempat mana yang terbaik dan cocok untuk dijadikan pusat kunjungan bagi anak-anak. Disisi lain, orangtua, harus mengajarkan berbagai macam tata krama, adab sopan santun jika ingin berkunjung serta bertamu disuatu tempat, dan ikut andil di dalamnya.

Anak usia Prasekolah yang dudukdi bangku Raudhatul Atfal (RA), Taman KanakKanak (TK), Bahkan Bustanul Atfal (BA),kerap sekali memerhatikan protokol pendidikan karakter yang harus ditanamkan di usianya yang masih dini. Sebut saja dengan geneasi emas, yaitu generasi golden age dimana generasi ini memerlupakn asupan bahkan stimulasi yang gemerlang untuk meningkatkan pertumbuhan serta perkembangannya. Dimulai dari pendidikan karakter, agama,bahasa, intelektual, jasmani, interaksi sosial dan emosional hingga kreativitas seni. Semua pendidikan tersebut mempunyai nilai positif bagi 
perkembangan anak dimasa dini. Maka perlu adanya kajian keilmuan untuk mendapatkan pengetahuan edukasi anak.

Edukasi ini merupakan bagian dari pendidikan Islam Anak Usia Dini yang harus diterapkan, dibiasakan, dicontohkan, diteladankan dari orangtua ke anak-anaknya. Jika kita lihat dari sudut pandang definisi Anak Usia Dini dalam berbagai teori, penulis mengambil teori dari peraturan menteri Pendidikan dan Kebudayaan (2014: 3) mengenai sebuah pembahasan Kurikulum 2013 PAUD mendefinisikan bahwasannya kategori Anak Usia Dini tergolong dalam anak balita berusia 0 hingga 6 tahun yang perlu mendapatkan penanganan intensif terhadap pola pertumbuhan serta perkembangannya. Impelemtasinya dapat berupa penanaman pendidikan karakter dimulai dari pembiasaan berbagai perilaku adab yang baik, hingga penguasaan intelektualiasi diri yang dapat diampikasikan pada masa depannya nanti (Ayuhan, 2016: 116).

Perihaltersebut, hendaknya orangtua, ataupun guru jika di Sekolah selalu mengajarkan anak didiknya adab bahkan perilaku yang baik bagi mereka, terutama adab saat berkumpul disuatu tempat, atau adabul majlis. Adabul masjlis merupakan salah satu dari ajaran Pendidikan Akhlak yang wajib diterapkan, diajarkan, dibiasakan, bahkan orangtua mencontohkanperilaku positif bagi anaknya ketika mereka ikut andil dalam suatu forum perkumpulan. Orangtua ataupun pendidikdianjurkan agar mengajarkan perilakusopan santun, bersabar,bersikap tawadhu' dalam bermajlis (Hakim, 2019:43). Penerapan edukasi karakter inibaik dilakukan bagi bangsa dan agama. Islam mengajarkan umatnya perihal adab dalam melakukan suatu apapun, tidakterkecuali saatbersosialisasi, berbudaya setanah air (Indrawan, 2016: 17).

Qur'anul Karim merupakan kitab suci umat muslim yang didalamnya terdapat berbagai macam sumber keilmuan hidup umat manusia. Tidak terkecuali pada pendidikan akhlak bagi bani adam. Mulai dari surah Al-Isro' ayat 23 yang mengandung makna adab birrul walidain bagi bani adam, kemudian surah Al-Luqman ayat 12-19 yang mengisahkan tentang peran orangtua dalam mendidik anaknya mengenai perilaku adabiyah seperti adab berjalan, ramah tamah, birrul walidainserta beberapa ilmu Ketauhidan (Najib, 2019: 111). Tidak cukup dengan dua surah yang menjelaskan mengenai pendidikan akhlak bagi bani adam, namun ada beberapa surah lainnya yang mengandung arti mendalam perihal adab untuk ditanamkan kepada generasi emas. 
Artikel ini memuat tentang keilmuan Islami bagi generasi emas, yaitu generasi usia prasekolah yang dibimbing berdasarkan keilmuan adabul majlis perspektif Al-Qur'an. Mengingat bahwa Qur'anul Karim adalah sumber pengetahuan seluruh umat, maka penulis ingin meneliti kandungan surah dari dalil kalam Ilahi ini dengan berlandaskan atas adabul majlis bagi generasi emas. Harapan dari penulis dengan adanya atikel ini dapat menambah wawasan keilmuan Islam bagi anak usia prasekolah tentang adab bekumpul serta bersosialisasi di lingkungan sekitar. Penulis juga mengkaji kurikulum 2013 PAUD sebagai patokan dasar untuk dijadikan sumber keilmuan tambahan dalam pengimplementasian nilai-nilai adabul majlis perspetif Qur'anul Karim.

Tujuan dari kajian ini tidak lain adalah agar para orangtua maupun pendidik memahami dan mengetahui tentang kajian edukasi akhlak dari segi adabul majlis dalam konteks Qur'anul Karim serta implikasinya dalam kurikulum 2013 PAUD perihal pencapaian perkembangan anak usia 4-6 tahun. Tujuan yang lainnya adalah agar dapat menambah wawasan bagi pendidik maupun orangtua mengenai metode pembelajaran edukasi adab bermajlis ketika menghadiri suatu perkumpulan ataupun acara yang melibatkan anak usia dini. Adanya hal ini diharapkan dapat menjadi kajian literatur Islam yang beredukasi bagi pengembangan tingkat pencapaian perkembangan anak usia dini dalam aspek agama dan moral.

\section{Metodologi}

Ketika hendak mengkaji suatu keilmuan, maka tidak luput dari suatu metodologi yang diterapkan dalam sebuah penelitian. Adapun metode yang diterapkan yaitu melaluilitera tur konteks isi. Studi literatur adalah bagian dari studi penelitian yang mengkaji beberapa literatur ilmiah yang berkaitan dengan cakupan konteks isi dalam naskah penelitian. Adapun yang digunakan penulis,ialah menggunakan buku-buku rujukan, bahkan kitab-kitab klasik berbahasa arab mengenai penafsiran Qur'ani tentang makna dibalik kata adabulmajlis dalam sebuah dalil Allah. Kajian ini termasuk dalam bidang penelitian kualitatif deskriptif yang penyajian artikelnya berupa kalimat frase dan bukan menggunakan sebuah perhitungan data.

Sumber rujukan data yang digunakan dapat berupa kitab Tafsir Ibnu Katsir, Tafsir Fathul Qodhir, Tafsir Al-Wasith serta Munjid Fil Lughoh. Semua kitab tersebut adalah 
referensi literatur yang penulis gunakan sebagai sumber data dasar untuk mencari dan menelaah makna dibalik kata adabul majlis perpesktif Qur'ani. Adapun sumber tambahan berupa literatur rujukan dari buku, peratuan menteri, jurnal, maupun situs web online yang membahas mengenai pendidikan generasi emas dalam mempelajari edukasi adabiyah khususnyaadabul majlis. Cara pengumpulan data yang digunakan melalui konten isi, yaitu sebuah teknik pengumpulan datadengan mendeskripsikan isi dari sebuah kajian literatur.

\section{Hasil dan Diskusi}

\section{Nilai-nilai Pembelajaran Adabul Majlis dalam Qur'anul Karim}

Sebelum kita membahas mengenai makna adabul majlis yang terkandung dalam Kitab suci kita kaum muslimin, maka hendaknya kita mengetahui terlebih dahulu makna secara harfiyah lughowiyah asli kata adabul majlis. Secara bahasa, kata adabul majlis diambil dari dua kata berbahasa arab yang berbunyi aduba-adabanyang artinya sopan atau berbudi luhur. Kata kedua,yaitu majlis yang mengandung makna suatu perkumpulan dari suatu kaum yang dikhususkan sebagai tempat berbagai kegiatan positif untuk mencari ilmu atau bersosialisasi (Masrik Ad, 2008).

Adapun tempat perkumpulan yang sering kali digunakan untuk bermajlis kaum muslimin ialah masjid, aula, auditorium, kelas, gedung, kantor dan masih banyak lagi tempat yang sering digunakan untuk kegiatan sehari-hari. Penulis memberi kesimpulan bahwa istilah adabul majlis berarti suatu tindakan positif, yang dilakukan oleh seseorang dengan memenuhi potokol adab yang baik saat sedang berkumpul (ikut duduk didalamnya) dengan berbagai kalangan disuatu acara tertentu. Pertemuan khusus yang sering digunakan dalam bermajlis dapat berupa urusan administrasi, sosial atau agama di negara-negara yang memiliki hubungan bahasa dan budaya secara Islam.

Adabul majlis dalam Islam perlu diterapkan dalam bersosialisasi. Tindakan yang dapat dilakukan dalam mengedukasi generasi emas, dapat berupa pembiasaan mengucapkan salam sebelumdan sesudah menghadiri majlis, meminta ijin jika ingin meninggalkan majlis, dudukdengan posisi tenang,nyaman dan sopan, selalu memerhatikan pembicara didepan panggung dengan seksama, tidak bolehbermain dan bermain sesuka hati, tertib, dan tidak boleh tidur dalam bermajlis (At-Tirnaty, 2017:3).

Islamic Gilrs Bording School Darul Marhamah juga menerapkan pendidikan bermalis yaitu dengan cara membiasakan mengucapkan salam sebelum bermajlis, masuk majlis lewat 
pintu yang telah disediakan, duduk pada tempatnya, tidak boleh mengganggu teman, bersikap sopan dan mendengarkan acara dengan seksama, dan tidak lupa membaca doa kafarotul majlis (afif, 2015:32). Perilaku beradab ini sangat dianjurkan untuk diajarkan oleh generasi milenial,terlebih oleh kaum generasi emas. Hal ini dikarenakan perilaku adab bermajlis merupakan sebuah tindakan yang bernilai positif pada ranah sosial Islam. Adab bertamu, salam, ramah, saling menghormati antara sesama merupakan kunci utama terjalin ukhwah Islamiayh antar umat beragama.(Khamim, 2018: 89).

Dalam pembahasan Adabul Majlis ini, ada beberapa dalil Qur'ani yang memperkuat dan dapat dijadikan pedoman bagi umat manusia. Adabul Majlis dalam Qur'anul Karim ada dalam Surah Al-Mujadalah ayat 11 yaitu

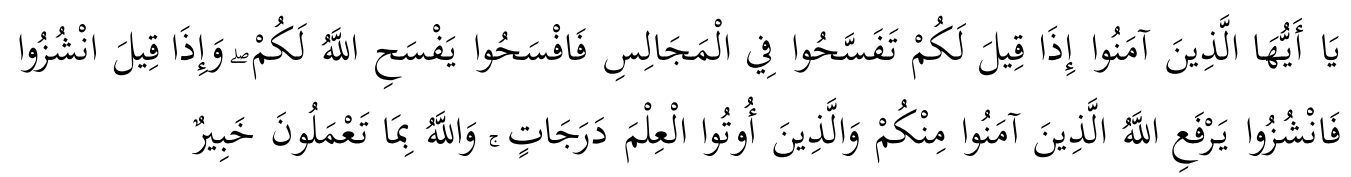

Makna dari kalam Ilabi ini adalah para umat manusia haruslab berlapang dada saat bermajlis. Jika disarankan untuk berdiri dari tempat duduk maka bedirilah. Jik a umat manusia melakukan hal ini, maka Allah akan meninggikan derajatnya dan akan diberikan ilmu pengetabuan sesuai dengan kemampuannya. Hal ini dikarenkan Allah adalab Tuban yang Maha mengetahui segala sesuatu atas perbuatan manusia selama berada di bumi.

Dalam Ayat tersebut menjelaskan bahwa kita sebagai umat Islam hendaknya ikhlas dalam bermajlis, artinya menerima segala ketentuan serta peraturan yang ada di majlis. Contohnya jika dimintai untuk berdiri atau pindah dari tempat duduk, maka harus menerima dengan ikhlas. Ketika diberikan nasehat oleh pembicara maka, harus menerima,mendengarkan tanggapan dan sanggahan dengan ikhlas. Tafsir Ibnu Katsir mengatakan bahwa;

Maha Suci Allab berfirman apabila bendak membimbing para hambanya yang beriman dan bertaqwa peribal peilaku berakblak, maka hendaknya barus bersikap lapang dada serta menerima dengan sabar saat berada disuatu majlis. Barangsiapa yang berlapang dada pada kala itu, maka Allah akan melapangkan segala urusan seperti memberikan hasil panen saat hambanya sedang menanam( Ar-Rifai, 2007: 465).

Jika ditelaah dan ditafsirkan dengan menggunakan Tafsir $A l-W$ asith maka pendapat ahlu tafsir meriwayatkan bahwa akidah Islam menyeru kepada kaumnya agar bersikap ikhlas dan berlapang dada saat sedang menghadiri pertemuan majlis. Hal disampaikan agar sebagain dari kaum muslimin selalu berperilkau adabiyah seperti tolong menlong,sabar, mencintai sesama umat,mempunyaibelas kasih serta berpegang teguh pada moralitas hormat patuh terhadap pembicaradan kaum orang lansia. Semua ini dilakukan agar 
membentuk pribadi yang unggul(Az-Zuhaili, 2013: 602). Kandungan surah Al-Mujadalah ayat 11 juga terdapat pesan khusus dalam pembelajaran adab berlapang dada yang bermakna mau bertoleran dalam ketertiban bermajlis, santun dalam menimba keilmuan di segala bidang dan usia yang bersifat indrawi (Sholeh, 2017: 206).

Penulis menganalisis dari kedua penafsiran tersebut maka, dapat ditarik jawaban bahwasannya ketika kita sedang bermajlis, hendaknya seorang hamba Allah berlapang dada dengan ikhlas menerima dari segala peraturan, pembicaraan, kedisiplinan yang ada di dala m majlis. Kita tidak diperbolehkan untuk berbuat gaduh atau bertengkar saat bermajlis. Hendaknya kita menghargai satu sama lain, mencintai dan menyanyangi sesama, karena siapa yang menanam maka dia akan mendapatkan hasil dari tanamannya tersebut. Maha suci Allah sangat kasih akan hambanya yang ikhlas menerima segala sesuatu dengan lapang dada, sikap kasih mengasihi, tolong menolong antar hambanya.

Adapun contoh perilaku yang beradab saat bermajlis yaitu ada pada surah AlBaqoroh ayat 189 yang bermakna; ketika kita hendak bertamu atau bermajlis di tempattempat pertemuan, maka kita harus memasuki rumah atau tempat majlis dari pintupintunya, bukan dari arah yang tidak diperbolehkan. Jika kamu mematuhinya maka kamu termasuk orang-orang yang bertaqwa (Departemen Agama RI, 2017: 29). Dari penjelasan disamping, jelas adanya bahwa umat manusia ketika hendak bertamu, maka ia hendak memasuki rumah itu pada pintu yang telah disediakan. Ini merupakan sebuah adab saat bertamu.

Jika kita kaitkan dengan penafsiran-penafsiran dikalangan para ahli tafsir dan kitabkitab tafsir yang mashur maka, pandangan dari tafsir Al-Mukhtashar berpendapat bahwa tidak ada etika seseorang bagi yang memasuki rumah bukan dari pintunya, melainkan dari atap atau dari belakangnya. Dan seseorang dikatakan bertaqwa apabila ia memasuki/keluar rumah ketika hendak bertamu, mereka melewatinya dari pintu yang telah disediakan (Kementrian Agama, 2019). Tafsir Fathul Qodhir menyatakan bahwa suatu kebaikan jika para jamaah haji, apabila hendak berpulang ke rumah masing-masing, maka diwajibkan mereka untuk memasuki rumah lewat pintu yang telah disedikan,yaitu lewat pintu depan. Ini merupakan suatu kebajikan yang nyata bagi mereka (Syaukan, 2008: 734).

Jika kita analisis dari kedua penafsiran dari surat Al-Baqoroh ayat 189 tersebut maka, dapat disimpulkan bahwa hendaknya kita sebagai seorang muslim memasuki kediaman rumah dengan memasukinya dari pintu depan bukan dari pintu belakang atau dari pintu manas saja. Hal tersebut adalah sebagaian dari adab bertamu. Seseorang yang memiliki budi 
pekerti yang baik, atau adab yang baik, maka mereka adalah termasuk orang-orang yang bertaqwa yang memeliki kebajikan yang baik, yaitu menaati peraturan bahwasaannya ketika kita bertamu atau hendak memasuki rumah, hendaknya memasukinya dari pintunya bukan dari jendelanya atau dari atapnya.

\section{Konsep Adabul Majlis bagi generasi Emas Prasekolah Islam}

Generasi emas, dapat dikategorekan dalam rentang usia 0-6tahun yang harus diberikan stimulus dan rangsangan dari kedua orangtua, ataupun pendidik. Tidak lupa pula agarmemberikan stimulasi berupa edukasi Islamiyah untuk anak, karena ini sangat penting untuk pembentukan kepribadinya kelak (Fakhrudin, 2010:27). Masa kanak-kanak ini membutuhkan berbagai macam stimulus untuk membantu perkembangannya. Pada masa ini pula otak anak bekerja, aktif, dan gesit dalam berinteraksi sosial (Suyadi, 2012: 27). Menurut penulis, ini adalah kesempatan yang besar untuk menciptakan generasi emas yang berakhlak mulia serta berbudi pekerti yang luhur.

Inilah saatnya untuk memberikan dukungan serta dorongan kepadanya agar kelak mereka menjadi pribadi yang berkarakter. Penerapan adabul majlis dapat dilakukan dengan cara pengaplikasian secara langsung dan tidak langsung. Ini adalah sebuah taktik untuk menerapkan sistem protokol edukasi akhlak sedini mungkin. Jika pengaplikasian seara langsung, maka pihak orangtua ataupun guru wajib mencontohkan dan memberikan teladan kepada anak. Jika melalui protokol tidak langsung, maka pihak guru wajib memberikan asupan berupa permainan ataupun cerita dongeng yang berkaitan erat dengan implementasi moral anak.(Zamroni, 2017: 12).

Adabul Majlis dalam Pendidikan generasi emas prasekolah Islam ini masuk kedalam materi Adab. Pada materi ini, anak-anak diajarkan mengenai adab dalam berperilaku dengan diri sendiri dan orang lain. Adapun materinya adab bertamu, hormat serta patuh kepada orang yang lebih tua dari kita, bertanggung jawab, adab berteta ngga dan mencintai umat manusia (Ummu Ihsan. dan Abu Ihsan., 2011: 95-97). Adabul majlis masuk dalam kategori pengembangan sosial untuk kanak-kanak generasi emas. Pengembangan sosial ini, membutuhkan peran orangtua serta pendidik dalam pengaplikasiannya. Mereka dapat memberikan kesempatan kepada anak agar bersosialisasi dengan lingkungan yang berdampak positif (Rohayati, 2018: 131) Menurut penulis, hal ini wajib diterapkan karena agar mereka dapat meniru segala kebiasaan yang ada dalam majlis. Orangtua ataupun pendidik harus mencontohkan yang baik bagi peserta didiknya. 


\section{Konteks Adabul Majlis dalam Kurikulum 2013 PAUD}

Kurikulum merupakan jantungnya edukasi di seluruh dunia. Tanpa adanya kurikulum pendidikan tidak akan jalan dengan maksimal. Segala aspek perkembangan dan pertumbuhan baik teknik pengajaran, evaluasi, bahkan rangcangan pembelajaran ada dalam kurikulum 2013 PAUD. Penulis menganalisis bahwa adanya penerapan nilai-nilai adabul majlis dalam konten kurikulum PAUD. Materi Adab dalam bermajlis masuk dalam materi Pendidikan Akhlak mulia bagi anak prasekolah (Kementrian Pendidikan Nasional, 2014: 9). Adanya hal ini, pihak guru beserta jajarannya ikut andil dalam penerapan edukasi karakter. Mereka harus melalukan beberapa tahap, diantaranya adalah sebagai pendidik, panutan, percontohan, konsultan, perancang pembejajaran adab, serta sebagai mediator (Maryatun, 2016:5).

Konteks kurikulum PAUD disusun berdasarkan pembelajaran saintifik. Pembelajaran ini menyakinkan anak agar dapat berekplorasi dalam bersosialisasi dengan orang lain. Hal ini dapat diterapkan dengan discovery learning agar dalam pembentukan karakter peduli sosial anak (Fauzi et al., 2017: 79). Penulis menganalisis Kopentesi Dasar dan Kompetensi Inti yang termasuk materi Adab dalam Bermajlis yang termasuk ke dalam habituation edukasi karakter mulia bagikanak-kanak prasekolah Islam. Berikut penulis paparkan berdasarkan Kompetensi Inti dan Kompetensi Dasar

Tabel 1. Kompetensi Inti dan Kompensi Dasar dalam Penerapan Nila-Nilai Adabul Majlis

\begin{tabular}{|c|c|}
\hline KOMPETENSI INTI (KI) & KOMPETENSI DASAR (KD) \\
\hline $\begin{array}{l}\text { KI-1.Menerima edukasi keagamaan yang } \\
\text { dipercai }\end{array}$ & $\begin{array}{l}1.1 \text { mampu menghargai diri sendiri, orang lain, dan } \\
\text { lingkungan sebagai bentuk kesyukuran nikmat Allah }\end{array}$ \\
\hline \multirow[t]{3}{*}{$\begin{array}{l}\text { KI-2. Mampu nenounyai jiwa empati dan } \\
\text { simpati pada orang lain, santun dalam } \\
\text { berprilaku serta berinteraksi dengan lingkungan } \\
\text { sosial, mampu memhargai keputusan orang lain }\end{array}$} & $\begin{array}{l}\text { 2.2 Memiliki perilaku yang berjiwa kesabaran (rela } \\
\text { mengantri dan menunggu giliran disetiap kegiatan } \\
\text { yang berkenanaan dengan sosial, mau } \\
\text { mendengarkantaujihat orang lain, melakukan } \\
\text { kedisilinan saat melakukan kegiatan. }\end{array}$ \\
\hline & $\begin{array}{l}\text { 2.3 Memiliki perilaku mau menghargai pendapat, } \\
\text { perbuatan kepada orang lain }\end{array}$ \\
\hline & $\begin{array}{l}\text { 2.4 Memiliki perilaku sopan dan baik terhadap orang } \\
\text { tua, pendidik, dan teman sekitar. }\end{array}$ \\
\hline
\end{tabular}

Sumber: Kurikulum 2013 PAUD: 2014 
Tabel diatas, menerangkan tentang adanya hubungan antara Kompeteni Inti dan Kompetensi Dasar dengan adanya materi Adabul Majlis dalam bermajlis yang akan akan disampaian dalam pembiasaan edukasi Akhlak Mulia pada prasekolah Islam. KI dan KD yang bersangkuttan ada dua aspek, yakni KI-1, dan KI2. KI-1 mengenai segi Spiritual, sedangkan KI-2 adalah tentang sosial anak. berikut penjelasan mengenai hubungan Adab Bermajlis dengan KI dan KD dalam Kurikulum:

KI-1 tentang menerima ajaran agama yang dianut dengan KD-1.1 yaitu Menghargai diri sendiri, orang lain, dan lingkungan sekitar sebagai rasa syukur kepada Tuhan. Dengan ini ketika anak usia dini sedang bertamu, atau bermajlis dengan orangtua atau guru maka diharapkan anak mampu menghargai dirinya, oranglain, dan lingkungan sekitar dengan santun. Hal ini masuk pada materi Adabul Majlis

KI-2 tentang Memiliki perilaku menghargai kepada orang mampu menyesuaikan diri, santun dalam berinteraksi dengan keluarga, pendidik, dan teman dengan KD 2.2, 2.3, 2.4 yang berisi bahwa anak mampu memiliki perilaku sabar dalam memasuki pintu-pintu majlis dengan bergiliran tidak berebutan, diharapkan mampu mendengarkan orang lain sedang berbicara didepan, berdisiplin artinya ketika memasuki pintu hendaknya lewat dari depan, bukan dari belakang, dan ketika sudah masuk dalam majlis diharapkan anak mampu duduk dengan tertib, dan tidak bergurau dengan temannya.

Kurikulum 2013 dalam PERMENDIKBUD no 146 Tahun 2014 PAUD juga menerangkan tentang adanya sebuah Indikator dan Tingkat Pencapaian Perkembangan yang dipacu dari usia anak. usia anak RA/TK/BA berkisar antara usia 4-6 tahun, maka dari itu penulis rangkum dan menganalisis Tingkat Pencapaian Perkembangan anak usia 4-6 tahun yang ada hubungannya dengan materi adabul Majlis dalam penerapan edukasi Islam bertaraf adabiyah akhlaqiyah terhadap kanak-kanak Prsekolah RA/TK/BA. Berikut penulis paparkan berdasarkan usia anak.

Tabel 2. Tabel Pengembangan Indikator Materi Adabul Majlissesuai dengan usia anak (4-5 Tahun)

\begin{tabular}{c|l|l}
\hline \multicolumn{1}{c|}{$\begin{array}{c}\text { Tingkat Pencapaian } \\
\text { Perkembangan }\end{array}$} & \multicolumn{1}{c}{$\begin{array}{c}\text { Capaian } \\
\text { Perkembangan }\end{array}$} & \multicolumn{1}{c}{ Indikator } \\
\hline $\begin{array}{l}\text { Mengenal Tuhan melalui } \\
\text { kepercayaan yang dianutnya }\end{array}$ & $\begin{array}{l}\text { Mengenal beberapa } \\
\text { dptaan Tuhan, seperti } \\
\text { manusia tumbuhan dll. }\end{array}$ & $\begin{array}{l}\text { Menyebutkan dan menyayangi beberapa } \\
\text { dptaan Tuhan, misalnya manusia, bumi, } \\
\text { langit, tanaman, dan hewan }\end{array}$ \\
\hline
\end{tabular}




\begin{tabular}{l|l|l|l}
\hline $\begin{array}{l}\text { Mengucapkan doa sebelum } \\
\text { dan sesudah melakukan } \\
\text { berprlaku }\end{array}$ & $\begin{array}{l}\text { Berdoa sebelumdan } \\
\text { sesudah melakukan } \\
\text { kegiatan bersama-sama }\end{array}$ & $\begin{array}{l}\text { Agar anak dapat membiasakan diri untuk } \\
\text { berdoa ketika bermajlis. }\end{array}$ \\
\hline $\begin{array}{l}\text { Membiasakan mengucapkan } \\
\text { salam dan membalas salam }\end{array}$ & $\begin{array}{l}\text { Melafadkan salam } \\
\text { sesudah dan setelah } \\
\text { melakukan sesuatu } \\
\text { kepada orag lain }\end{array}$ & $\begin{array}{l}\text { Agar anak dapat menerapkan salam saat } \\
\text { bertemu kepada orang lain, saat bertamu, } \\
\text { serta menghadiri acara majlis ta'lim }\end{array}$ \\
\hline $\begin{array}{l}\text { mengenal perilaku yang } \\
\text { bermoral sesuai ajaran agama }\end{array}$ & $\begin{array}{l}\text { Berprilaku sopan serta } \\
\text { baik dalam berpakaian, } \\
\text { bertutur kata, serta } \\
\text { bertingkah laku ketika } \\
\text { bersosialisasi }\end{array}$ & $\begin{array}{l}\text { Agar anak dapat menerapkan berpakaian } \\
\text { rapi di rumah dan di sekolah } \\
\text { Agar anak dapat berpakaian rapi yang } \\
\text { disesuaikan dengan keperluan }\end{array}$ \\
\hline
\end{tabular}

Tabel 3. Tabel Pengembangan Indikator Materi Adabul Majlis sesuai dengan usia (5-6

\begin{tabular}{|c|c|c|}
\hline \multicolumn{3}{|c|}{ Tahun) } \\
\hline $\begin{array}{c}\text { Tingkat Pencapaian } \\
\text { Perkembangan }\end{array}$ & Capaian Perkembangan & Indikator \\
\hline $\begin{array}{l}\text { Mengenal kepercyaan } \\
\text { akidah yang dimiliki anak }\end{array}$ & $\begin{array}{l}\text { Mengetahui informasi } \\
\text { beberapa tempat } \\
\text { peribadatan sesuai agama } \\
\text { masing-masing. }\end{array}$ & $\begin{array}{l}\text { Agar anak dapat memperoleh informasi serta } \\
\text { menyebutkan beberapa tempatperibadatan } \\
\text { umat manusia. }\end{array}$ \\
\hline $\begin{array}{l}\text { Menerapkan perilaku } \\
\text { mulia (sopan, hormat) }\end{array}$ & $\begin{array}{l}\text { Melatih anak agar terbiasa } \\
\text { berperilaku sopan dan } \\
\text { santun, serta saling } \\
\text { hormat menghormati } \\
\text { antar umat. }\end{array}$ & $\begin{array}{l}\text { Diharapkan agar anak dapat berbicara dengan } \\
\text { sopan serta berbusana rapi, hormat dan patuh } \\
\text { pada guru, dan selalu mendengarkan, } \\
\text { memerhatikan ceramah, edukasi dari guru }\end{array}$ \\
\hline
\end{tabular}

Tabel diatas, menunjukkan bahwa adanya hubungan antara adabul majlis dengan pencapaian perkembangan anak usia 4-6 tahun dalam kurikulum 2013 di Prasekolah. Hubungan yang didapat adalah anak dapat belajar akan sebuah pembiasaan dalam pengucapan salam ketika memasuki majlis di sebuah tempat perkumpulan. Setelah berkumpul dalam satu majlis, diharapkan anak dapat melafadzkan surah Al-Fatihah sebagai surah pembuka dalam bermajlis. Para guru dapat mengajarkan pembiasaan melafadzkan surah Al-Fatihah dengan takrir atau melafadzkan secara bersamaan dalam satu majlis. Selain itu anak dapat belajar membiasakan diri untuk bersikap sopan santun, mendengarkan ceramah dengan baik dan seksama tanpa gaduh, berpakaian rapi dan bersih ketika bermajlis serta memasuki majlis perkumpulan secara tertib. Semua hal ini sudah menjadi tanggung jawab guru dalam mencontohkan anak didik ketika berada disebuah majlis.

Penulis mengambil contoh di usia 4-6 tahun ada sebuah tingkat pencapaian yakni anak mengenal dan membiasakan membaca doa, mengucapkan salam sebelum dan sesudah melakukan kegiatan. Ketika berada di majlis, maka tugas orangtua atau guru memberikan contoh, membiasakan mereka dalam mengucapkan salam dan mengucapkan doa ka fa rotul majlis jika selesai acara. Hal ini juga telah diaplikasikan di berbagai lembaga PAUD. Guru 
menjadi panduan utama dalam pengimplementasian nilai-nilai pendidikan karakter, terutama nilai-nilai adab bertamu (Fertiliana et al., 2019: 112). Kurikulum KTSP juga sehubungan dengan adanya nilai-nilai edukasi karakter dalam pengaplikasiannya. Indikator yang dijalankan dapat berupa salam, sapa, sopan dan santun terhadap kaum tua ke kaum muda. Kaum muda disini adalah para generasi emas yang berjiwa sosial yang memiliki empati dan simpati (Sucipto, 2011).

Pendidik serta orangtua dapat mengajarkan kepada anak-anak mengenai doa dari Rasulullah, yaitu doa kafarotul Majlis. Doa ini mempunyai makna yang sangat mendalam dalam ranah majlis ta'lim. Penerapan doa kafarotul majlis sudah menjadi tatanan adab dalam aplikasi nilai-nilai adabul majlis bagi kanak-kanak. Adapun doa kafarotul majlis sebagai berikut:

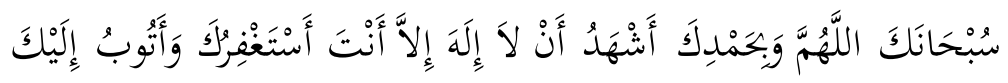

Makna dari doa kafarotul majlis yang diajarkan terhadap kanak-kanak prasekolah Islam adalah suatu doa dari pengampunan dosa saat sedang bermajlis di tempat. Doa ini diriwayatkan langsung oleh Abu Daud pada saat Rasullah saw sedang berdiskusi dengan seseorang ketika berada dalam satu majlis. Rasullah menyara nkan agar selalu membaca doa kafarotul majlis sesudah bermajlis. Hal ini dilakukan agar Allah mengamuni dosa hamba pada saat bermajlis (Abdus-Salam, 2004: 327).

Doa tersebut diucapkan ketika akan berpisah atau akan selesai dari suatu majelis. Majelis ini tidak hanya dengan duduk pada tempat perkumpulan, akan tetapi doa ini dibaca ketika selesai berdiskusi, belajar, bermain, dan bercerita. Setiap pembicaraan atau obrolan biasa apalagi diyakini ada perkataan sia-sia yang terucap, maka doa kafaratul majelis sangat dianjurkan untuk dibaca. Jika suatu majelis atau tempat obrolan yang tidak membica rakan hal mengenai akhirat melainkan hanya hal dunia saja dan didalamnya tidak terdapat dzikir pada Allah, maka doa kafarotul majlis menjadi penghapus dosa. Hal ini diterapkan oleh lembaga PAUD yang ada di Lombok Timur pada masa pandemi covid 19 dengan penugasan kepada anak mengenai hifdzu doa-doa harian, termasuk doa kafarotul majlis. (Nahdi et al., 2020:177).

\section{Metode Pengajaran Edukasi Adabul Majlis bagi Anak Usia Dini}

Suatu pembelajaran tidak luput dari suatu metode dalam pengaplikasiannya. Metode digunakan sebagai cara untuk memudahkan para pendidik dalam memberikan edukasi kepada anak usia dini. Hal ini diperlukan metode yang cocok untuk diterapkap. Seorang 
pendidik baik orangtua maupun guru hendaknya terjun langsung untuk mempraktekkan perilaku yang baik pada anak diusianya yang masih belia. Adanya pembiasaan perilaku positif dari pihak guru maupun orangtua merupakan kunci suksesnya penerapan nilai-nilai adabul majlis ini. (Cahyaningrum et al., 2017). Adapun metode pembelajaran adab bermajlis bagi anak usia dini yang dapat diterapkan oleh pendidik sebagai berikut;

\section{Metode Keteladanan}

Metode ini dapat digunakan untuk mengajarkan materi adab kepada anak-anak. Metode ini dijuluki metode efektif dan berhasil dalam mempersiapkan anak dari segi akhlak, ibadah, adab dan keimanan karena pendidik adalah contoh yang paling tinggi untuk membimbing dan memberikan contoh yang baik kepada anak-anak. (Ulwan, 2013: 476). Metode ini melibatkan peran orangtua ataupun pendidik untuk mengembangkan berbagai aspek perkembangan anak, khususnya agama dan moral anak yang melibatk an pendidikan akhlak (Nurjannah, 2017:203). Teknik pengajarannya adalah guru mencontohkan akan arti hidup sosialiasi, hidup bermasyarakat, beribadah, bertutur kata yang baik, sopan terhadap orang asing, bahkan mendengarkan petuah saat sedang berbicara didepan publick.. Jadi menurut penulis ada kecocokan untuk mengajarkan adabul bermajlis dengan metode keteladanan, dengan cara memberikan contoh yang baik dalam bermajlis, contohnya ketika kita sedang duduk bersama-sama maka adab kita adalah duduk dengan sopan, mendengarkan orang yang berbicara di depan, menjawab salam ketika ada orang yang memberi salam, dan memasuki rumah majlis dari pintu yang telah disediakan.

\section{Metode Pembiasaan}

Metode ini dapat diterapkan melalui peran dan tanggung jawab pendidik bagi orangtua maupun guru untuk membiasakan anak agar melakukan hal positif sesuai dengan moralitas dan akidah (Wendi, 2017: 102). Contoh dari metode ini adalah pembiasaan dalam pengucapan salam, perilaku hormat mengormati antara yang tua sampai ke yang muda. Kelebihan lain dari penggunaan metode pembiasaan dalam pengembangan nilainilai adabiyah dapat berupa penimbulan kemandirian, organistatoris, serta wawasan terhadap tanggung jawab kepribadian anak atas perilaku yang mereka terapkan sebagai bahan untuk rutinitas (Ayu \& Junaidah, 2019: 210). Pendidik dapat membiasakan anakanak berbuat sopan, tertib dan melakukan pembiasaan kedisiplinan saat berada di majlis. Selain hal tersebut, pendidik dapat membiasakan anak untuk melafadzkan doa kafarotul 
majlis setelah acara majlis selesai, dan membiasakan anak agar menjawab salam ketika ada orang yang memberikan salam saat pembukaan dan penutupan majlis.

\section{Metode Nasehat}

Metode ini merupakan metode yang efektif dalam mengajarkan nilai-nilai adab yang baik bagi anak (Huda, 2008: 67). Teknik pengajarannya bagi anak usia dini adalah melalui pendidik atau orangtua untuk menasehati serta mengarahkan terhadap halyang positif yaitu dengan bersikap sopan, tertib ketika bermajlis. Tidak lupa pula para pendidik juga mewajibkan anak untuk menasehati anak didik jika mereka melanggar aturan atau tidak tertib dalam bermajlis. Pendidik juga dapat menggunakan reward atau hadiah sebagai acuan untuk mereka semangat dan tertib selama mengikuti acara bermajlis. Guru harus menyakinkan anak dengan berbagai kata-kata motivasi, reward yang menggugah mereka agar bangkit serta berusaha menjadi anak yang baik(Fadlun, 2016:17).

\section{Metode Pengawasaan}

Metode ini digunakan oleh para pendidik baik orangtua maupun guru untuk mengawasi dan memerhatikan anak ketika sedang bermajlis. Tokoh Al-Gozali selalu menerapkan metode ini untuk membimbing anak dalam menempuh studi moralitas yang berkahlak mulia. Beliau menerangkan agar pendidik ikut andil dalam proses pengawasan, serta perhatian terhadap perilaku anak dalam kesehariannya (Rahmawati, 2019: 12). Metode pengawasan sangat penting dilakukan untuk penbelajaran pendidikan akhlak mulia dalam segi adabul bermajlis untuk anak. Guru ataupun orangtua memperhatikan dan mengawasi segala gerak gerik anak dalam bermajlis. Jika ada anak yang melakukan perbuatan yang tercela maka tugas guru adalah menegurnya dan memberikan pengarahan kepadanya. Pendidik dapat membantu anak dalam melafadkan doa kafarotul majlis jika mereka belum hafal, membantu anak untuk mengatur tempat duduk mereka, dan memberikan pengawasan jika anak tidak tertib saat acara majlis dimulai.

\section{Penutup}

Kajian edukasi akhlak perihal adab bermajlis dalam konteks Al-Qur'anul Karim tertera dalam surah Al-Mujaddalah ayat 11 dan surah Al-Baqoroh ayat 189 yang mengandung makna berlapang dada ketika bermajlis dengan bersikap ikhlas dan mema tuhi aturan dan tata tertib saat bermajlis. Adabul majlis dalam konteks kurikulum 2013 Prasekolah berhubungan erat dengan tingkat pencapaian perkembangan anak usia 4-6 tahun dalam aspek agama dan moral anak. Anak usia prasekolah 4-6 tahun diajarkan akan 
bersikap sopan santun, tertib serta mematuhi aturan saat bermajlis. Anak prasekolah juga diajarkan akan pembiasaan mengucap dan menjawab salam saat bermajlis, melafadzkan doa iftitah, dan doa kafarotul majlis saat penutupan acara. Anak prasekolah juga dajarkan akan selalu berpakaian rapi ketika menghadiri majlis. Diharapkan para pendidik baik dari orangtua maupun guru selalu menerapkan adab saat bermajlis dengan menggunakan metode keteladanan, pembiasaan, nasehat, serta pengawasan saat bermajlis. Pendidik bertanggung jawab dalam mencontohkan perilaku adab yang baik dengan selalu mengarahkan anak untuk berbuat sopan santun untuk mendengarkan ceramah saat bermajlis.

\section{Daftar Pustaka}

--, S. (2011). Rintisan Pengembangan Pendidikan Karakter di Satuan Pendidikan. Jurnal Pendidikan Dan Kebudayaan. https://doi.org/10.24832/jpnk.v17i5.45

Abdullah Nashih Ulwan. (2013). Kitab Tarbiyyatul AuladFil Islam. PT Darussalam.

Abdus-Salam, M. (2004). Bid'ah-Bid'ahyang Dianggap Sunnah. Qisthi Press.

afif, A. (2015). Adab dan Akblakserta Aturan Yang Baik. Islamic Gilrs Bording School Darul Marhamah.

At-Tirnaty, I. B. (2017). "Adabul Majlis dan Kesalahan-kesalahannya serta Bid'ab-Bidabnya." Maktabatul Abu Salmah Al-Atsari.

Ayu, S. M., \& Junaidah, J. (2019). Pengembangan Akhlak pada Pendidikan Anak Usia Dini. AL-ID ARAH: JURN AL KEPENDIDIKAN ISLAM. https://doi.org/10.24042/alidarah.v8i2.3092

Ayuhan. (2016). Konsep Pendidikan Anak Salih dalam Perseptif Islam. PT Deepublish. Az-Zuhaili, W. (2013). Tafsir Al-W asith. Gema Insani.

Cahyaningrum, E. S., Sudaryanti, S., \& Purwanto, N. A. (2017). PENGEMBANGAN NILAI-NILAI KARAKTER ANAK USIA DINI MELALUI PEMBIASAAN DAN KETELADANAN. Jurnal Pendidikan Anak. https://doi.org/10.21831/jpa.v6i2.17707

Departemen Agama RI. (2017). Al-Qur'an dan Tarjamah (Hamdan Permada (ed.)). PT Suara Agung.

Fadlun, M. (2016). Pendidikan Akhlak pada Anak Usia Balita. Jurnal Kependidikan. https://doi.org/10.24090/jk.v4i1.2805 
Fakhrudin, A. U. (2010). Sukses Menjadi Guru TK/PAUD,. Pustaka Pelajar.

Fauzi, A. R., Zainuddin, Z., \& Atok, R. Al. (2017). Penguatan Karakter Rasa Ingin Tahu dan Peduli Sosial melalui Discovery Learning. Jurnal Teori Dan Praksis Pembelajaran IPS. https://doi.org/10.17977/um022v2i22017p079

Fertiliana, L., Amalia, D. R., \& Laili, N. (2019). Peranan Kedisiplinan Guru Terhadap Perkembangan Karakter Baik Anak Usia Dini di Raudlatul Athfal Ma'arif 1 Metro Tahun Ajaran 2018/2019. SELING: Jurnal Program Studi PGRA. https://doi.org/10.29062/seling.v5i2.435

Huda, M. (2008). Idealis Pendidikan Anak. UIN Maulana Malik Ibrahim Malang. Indrawan, I. (2016). PENDIDIKAN KARAKTER DALAM PERSPEKTIF ISLAM. AlAfkar: Jurnal Keislaman \& Peradaban. https://doi.org/10.28944/afkar.v2i1.90

Kementrian Agama. (2019). TafsirWeb: Tafsir Surat Al-Baqoroh 189. Al-Quran Online.

Kementrian Pendidikan Nasional. (2015). Peraturan Menteri Pendidikan dan Kebudayaan Replubik. Indonesia No.137 Tabun 2013.

Khamim, K. (2018). THE URGENCY OF IMPROVING SOCIAL PIETY IN THE PERSPECTIVE OF TARBAWI HADITH (HERMENEUTIC ANALYSIS ABOUT COMMUNITY LIFE). Didaktika Religia. https://doi.org/10.30762/didaktika.v6i1.1096

Lukmanul Hakim. (2019). Konsep Pendidikan Karakter Peespektif K.H Hasyim Asy'ari Studi Kitab Adabul 'Alim Wal Muta'alim. Mediakita., JurnalKomunikasi Dan Penyiaran Islam, 3(1). https://doi.org/https://doi.org/10.30762/mediakita.v3i1.1800

Maryatun, I. B. (2016). PERAN PENDIDIK PAUD DALAM MEMBANGUN KARAKTER ANAK. Jurnal Pendidikan Anak. https://doi.org/10.21831/jpa.v5i1.12370

Masrik Ad, D. (2008). Al-Munjid Fil Lughoh. Maktabatul Syarkiyah.

Menteri Pendidikan dan Kebudayaan. (2015). Peraturan Menteri Pendidikan dan Kebudayaan No.146. Kurikulum 2013 Tabun 2014.

Nahdi, K., Ramdhani, S., Yuliatin, R. R., \& Hadi, Y. A. (2020). Implementasi Pe mbelajaran pada Masa Lockdown bagi Lembaga PAUD di Kabupaten Lombok Timur. Jurnal 
Obsesi : Jurnal Pendidikan Anak Usia Dini. https://doi.org/10.31004/obsesi.v5i1.529

Najib, F. A. (2019). Kontruksi PESAN Lukman Al-Hakim di QS. Luqman: ( Analisis Parenting Al-Qur'an). At-Tajdid: Jurnal Pendidikan Dan Pemikiran Islam, 3(2), 111. https://doi.org/htpp://dx.doi.org/10.24127/att.v3i2.1121

Nasib Ar-Rifai, M. (2007). Ringkasan Tafsir Ibnu Katsir. Gema Insani.

Nurjannah, N. (2017). MENGEMBANGKAN KECERDASAN SOSIAL EMOSIONAL ANAK USIA DINI MELALUI KETELADANAN. Hisbab: Jurnal Bimbingan Konseling Dan Dakwah Islam. https://doi.org/10.14421/hisbah.2017.141-05

Rahmawati, M. (2019). MENDIDIK ANAK USIA DINI DENGAN BERLANDASKAN PEMIKIRAN TOKOH ISLAM AL-GHAZALI. Al Fitrab: Journal Of Early Childhood Islamic Education. https://doi.org/10.29300/alfitrah.v2i2.2271

Rohayati, T. (2018). PENGEMBANGAN PERILAKU SOSIAL ANAK USIA DINI. Cakrawala Dini: JurnalPendidikan Anak Usia Dini. https://doi.org/10.17509/cd.v4i2.10392

Sholeh, S. (2017). Pendidikan dalam Al-Qur'an (Konsep Ta'lim QS. Al-Mujadalah ayat 11). Jurnal Pendidikan Agama Islam Al-Thariqah. https://doi.org/10.25299/althariqah.2016.vol1(2).633

Suyadi. (2012). ModelPendidikan KarakterPada Satuan Pendidikan Anak Usia Dini Islam. UIN Sunan Kalijaga Yokyakarta.

Syaukan, iImam A. (2008). Tafsir FathulQodir. Pustaka Azzam.

Ummu Ihsan. Abu Ihsan. (2011). Mencetak Generasi Rabbani. PT Darul Ilmi Publishing.

Zaman, Wendi. (2017). Ternyata Mendidik Anak Cara Rasulluab Mudab dan Efektif. PT Publising.com.

Zamroni, A. (2017). STRATEGI PENDIDIKAN AKHLAK PADA ANAK. Sawwa: Jurnal Studi Gender. https://doi.org/10.21580/sa.v12i2.1544 